Zbornik Instituta za kriminološka

i sociološka istraživanja

2021 / Vol. XL / 1 / 85-102

Pregledni naučni rad

Primljeno: 30. novembra 2020. godine

Prihvaćeno: 26. januara 2021. godine

DOI: $10.47152 /$ ziksi2021015

UDK: 305-055.2:174.6

\title{
KARAKTERISTIKE KOCKANJA KOD ŽENA
}

\author{
Slađana Milošević*
}

Cilj ovog rada je razmatranje rezultata istraživanja o karakteristikama kockanja žena $i$ objašnjenja rodnih razlika u kockanju. Kockanje danas predstavlja opšteprisutnu multidimenzionalnu društvenu pojavu koja uključuje sve veći broj populacije. Upravo, zbog uticaja na ukupnu stopu problema $s$ kockanjem u opštoj populaci̋i $i$ što je još važnije, na određene rizične grupe u populaciji, najpre mlade, odrasle kako muškarce tako $i$ žene izaziva veliku zabrinutost. Uprkos proceni da jednu trećinu kockara čine žene, većina postojeće literature o kockanju se uglavnom fokusirala na ponašanje $i$ stavove muškaraca u vezi sa kockanjem. Komparativnim analizama između muškaraca i žena uočavaju se razlike u karakteristikama kod žena kao što su: demografska senzitivnost, progresija zavisnosti, motivacija i izbor kockarskih aktivnosti. Žene često zbog sramote $i$ straha od stigmatizacije odlažu da potraže stručnu pomoć. Bolje razumevanje rodnih razlika kod žena je neophodno da bi se definisale efikasne strategije prevencije $i$ primenjivali rodno senzitivni programi lečenja.

KLJUČNE REČI: zavisnost od kockanja / kockanje žena / motivacija / vrste kockarskih igara

\footnotetext{
* Institut za mentalno zdravlje, Beograd. E-mail: sladjanamilo@gmail.com
} 


\author{
Zbornik IKSI, 1/2021 - S. Milošević \\ „Karakteristike kockanja kod žena”, (str. 85-102)
}

\title{
UVOD
}

Za čoveka, igra predstavlja oblik ponašanja koje je utkano u samo njegovo biće i njegovu društvenu stvarnost i percepciju sveta. Iz tog razloga, često se fenomen igre uzima zdravo za gotovo, bez dubljih tumačenja i razumevanja egzistencijalne i stvaralačke svrhe koju ona poseduje. Kako je igra u tesnoj vezi sa srećom, s jedne strane, kao stvaralac privremene, kratkotrajne sreće u trenutku njenog odigravanja i, s druge strane, sreća se vidi kao rezultat rizika usled igre (igre na sreću) i vezuje se za njenu materijalnu stranu, novac ili predmete od vrednosti (Koprek, 2013). Kako su čoveka od davnina privlačili neplanirani dobici, pa se s pravom može reći da ima dugu istoriju, s obzirom na to da podaci ukazuju na postojanje kockanja i pre pojave novca kao sredstva plaćanja. Dakle, kockanje postoji koliko i ljudsko društvo. Ali suprotno igri kao potpunoj slobodi, kod igara na sreću u glavni kadar dolaze čovekov nagon i iracionalnost (Božović, 2013). Ovakva iracionalna ponašanja stvaraju temelje za razvoj patološkog u čoveku, s toga danas svedočimo prekomernoj zavisnosti od igara na sreću i njenog štetnog uticaja na čovekovu egzistenciju, ali i na društvo čiji je član.

Brzi rast i dostupnost nije iznenađenje, ako se u obzir uzmu sve naklonjeniji stavovi društva prema kockanju kao obliku zabave, interesi države kao mogućnost povećanja nacionalnih prihoda, otvaranja novih radnih mesta, interesa lokalne zajednice da ojača turizam i time ekonomski razvoj (Binde, 2009; Tse et al., 2012). U skladu sa tim, danas se sa pravom o kockanju govori kao o opšteprisutnoj, multidimenzionalnoj društvenoj pojavi, u koju se uključuje sve veći broj populacije (Bjelajac, 2017). Ipak, sve ovo izaziva zabrinutost zbog uticaja na ukupnu stopu problema s kockanjem u opštoj populaciji i što je još važnije, na određene rizične grupe u populaciji, najpre mlade (Gupta \& Derevensky, 2000), starije odrasle osobe (Petry, 2002) i žene (Ladd \& Petry, 2002).

Uprkos proceni da jednu trećinu kockara čine žene, većina postojeće literature o kockanju se uglavnom fokusirala na ponašanje i stavove muškaraca u vezi sa kockanjem. To i ne predstavlja iznenađenje, jer se kockanje smatralo aktivnošću u kojoj dominiraju muškarci, odnosno postojanje više stope učešća, ali i štete u poređenju sa ženama (Abbott, Romild \& Volberg, 2018; Delfabbro, 2002). Iako se kockanje, kao pretežno muška aktivnost, postepeno menja i u sve većoj meri ustupa mesto ženama i danas se prevalenca zavisnosti od kockanja kreće 3:1 do 2:1 u korist muškaraca u odnosu na žene (Håkansson \& Widinghoff, 2020; Tavares et al., 2001). Ovakav podatak se neretko pripisuje liberalizaciji zakona o kockanju, promeni rodnih uloga, ekonomskim resursima koji su ženama na raspolaganju i otvaraju prostor za sve veće kockanje žena. $\mathrm{S}$ druge strane, kao objašnjenje da povećano učešce žena u kockarskim aktivnostima ne iznenađuje ukoliko se osvrnemo i na povećani udeo žena u zavisnosti od alkohola i drugih psihoaktivnih supstanci (Farré et al.,2015; Gambling Comision, 2017; Khanbhai, Smith \& Battersby, 2017; Merkouris et al., 2016). Bilo kako bilo, u svemu ovome ne treba zanemariti 


\author{
Zbornik IKSI, 1/2O21 - S. Milošević \\ „Karakteristike kockanja kod žena”, (str. 85-102)
}

pokazatelje individualnih razlika, kulturnu zasnovanost, dostupnost i društvenu prihvatljivost.

Komparativna analiza prevalence kockanja sprovedena u Južnom Velsu iz 2011. godine ukazuje da se $64 \%$ žena kockalo bar jednom u toku godine u poređenju sa 66\% muškaraca (Sproston, Hing \& Polankay, 2012). Na sličnu zastupljenost ukazuju i druga istraživanja, na Novom Zelandu u periodu od godinu dana praćenja oko 80,3\% žena se kockalo u odnosu na 80,4\% muškaraca (Abbott, Romild \& Volberg, 2018). Prevalenca kockanja žena u Velikoj Britaniji pokazuje da je $44 \%$ žena u odnosu na 53\% muškaraca učestvovalo u nekom obliku kockanja u poslednjih četiri nedelje (Gambling Comision, 2017).

Sve navedeno ukazuje na potrebu sagledavanja rodno specifičnih faktora koji utiču na kockarske aktivnosti žena. Cilj ovog rada je razmatranje rezultata istraživanja o karakteristikama kockanja žena i objašnjenja rodnih razlika u kockanju.

\title{
POJMOVNO ODREĐENJE KOCKANJA I ZAVISNOSTI OD KOCKANJA
}

Kockanje ili kocka je zajednički naziv za sve hazardne igre koje uključiju ulaganje novca, uz rizik i nadu u očekivanju pozitivnog ishoda, tj. da će igrač dobiti ono što je uložio ili više od toga (Jasaeri \& Bin Habil, 2012; Koić i dr. 2009). Kockanje slično definišu Korn i Šafer i navode da kockanje uključuje reskiranje nečeg vrednog $\mathrm{s}$ obzirom na ishod događaja na koji osoba ne može uticati, budući da je pobeda, odnosno gubitak određen srećom (Korn \& Shaffer, 1999 prema Grant, Desai \& Potenza, 2009).

Sam kontinuum kockanja se kreće od opuštajućeg rekreativnog koje nema štetnih posledica, preko problematičnog sa određenim posledicama na individualnom i porodičnom planu do kockanja koje prevazilazi opseg igre i kontrole, tj. postaje patološko (Ashley \& Boehlke, 2012). U skladu s tim, društveno rekreativni tip kockanja traje određeni vremenski period uz prihvatljive rizike i gubitke, može biti epizodično (manje od jednom u mesec dana) ili redovno (barem jednom u mesec dana). Osoba uglavnom kocka u društvu prijatelja ili kolega.

Problematični tip kockanja, s jedne strane obuhvata kockanje osoba sa rizikom od razvoja problematičnog kockanja (kockanje je često i ponavlja se u poslednjih 18 meseci) i kockanje osoba visokog rizika za razvoj problematičnog kockanja, s druge strane. Problematično kockanje je kockanje koje počinje stvarati određene probleme u ličnom i porodičnom funkcionisanju, školovanju, poslu i finansijama. Konkretno stvara tri ili četiri problema u različitim aspektima života (Subramaniam et al., 2017).

O patološkom kockanju ili zavisnosti od kockanja se može govoriti kada osoba nije u stanju kontrolisati svoj impuls za kockanjem, te kockanjem šteti sebi i drugima. Ogleda se u učestalom kockanju u poslednjih 18 meseci i stvaranju pet i više problema povezanih sa kockanjem. Pojam patološkog kockanja se upotrebljavao u Diagnostic and Statistical Manual and Mental Disorders-DSM-IV sve do 2013. 


\author{
Zbormik IKSI, 1/2021 - S. Milošević \\ „Karakteristike kockanja kod žena”, (str. 85-102)
}

godine kada je patološko kockanje bilo svrstano u poremećaje nagona i kontrole impulsa (F63.0).

Od 2013. godine prema petom izdanju Dijagnostičkog i statističkog priručnika za mentalno zdravlje i poremećaje (DSM-V) ranije patološko kockanje je rekvalifikovano kao „zavisnost i srodni poremećaji“, zajedno sa poremećajem upotrebe alkohola i droga. Znaci i simptomi zavisnosti od kockanja su:

- preokupiranost kockanjem uz konstantno pribavljanje više novca,

- izražena potreba za kockanjem sa sve većom količinom novca kako bi se doživelo uzbuđenje,

- bezuspešno pokušavanje da se kockanje kontroliše, smanji ili zaustavi,

- uznemirenost i razdražljivost kada se pokušava smanjiti ili prestati kockati,

- kockanje kako bi se izbegli problemi ili ublažio osećaj bespomoćnosti, krivice, anksioznosti ili depresije,

- pokušaj da se kockanjem vrati izgubljeni novac,

- laganje članova porodice i drugih lica kako bi se sakrila učestalost i razmere kockanja,

- urušavanje ili prekidanje međuljudskih odnosa,

- obezbeđivanje novca za kockanje kroz pribegavanje prevarama i krađama ili pozajmljivanje od drugih (Koić i dr. 2009; Petry et al., 2013).

Sličnosti zavisnosti od kockanja sa drugim poremećajima zavisnosti se ogledaju u: gubitku kontrole, preokupiranosti, disfunkcionalnosti u sferama ličnog, porodičnog, profesionalnog i socijalnog funkcionisanja, stigmatizaciji, nepostojanju rešenosti i motivacije samog zavisnika za lečenje.

S druge strane, razlike uključuju: nerealne fantazije o uticaju i uspehu, kognitivne distorzije, iracionalno ponašanje koje je suprotno od zdravog razuma i logike (Petry et al., 2013).

\title{
TEORIJSKA POZADINA RODNE RAZLIKE KOCKANJA
}

Sagledavanje razlike kockanja žena i muškaraca je najpre u literaturi propraćeno kroz prizmu nekoliko teorija. To su: teorije socijalnog kapitala, kulturno geografske teorije i teorije rodne uloge i socijalizacija.

Teorija socijalnog kapitala- rasvetljava motivaciju žena za kockanje. Prema ovoj teoriji je način bežanja od svakodnevnog pritiska koji mogu biti sastavni deo života žena kada se suočavaju sa osećanjem otuđenosti od zajednice ili konfuzijom socijalnih normi (Kawashi \& Berkman, 2001 prema Holdsworth, Hing \& Breen, 2012). Osnovna ideja ove teorije je da interpersonalne povezanosti imaju posebnu vrednost. Uspostavljanje i doživljavanje veze sa drugima od suštinske važnosti za psihičko i fizičko blagostanje pojedinca, kroz pružanje podrške što doprinosi osećaju pripadnosti i povezanosti (Nuske, Holdsworth\& Breen, 2016). Takođe i drugi autori 
potvrđuju da su socijalna izolacija, nepovezanost su doprinoseći faktori koji pokreću kockarske aktivnosti (Toneatto \&Wang, 2009). Dakle, kockanje je problem ranjivih, usamljenih žena, a kazina i klubovi postaju socijalno sigurno okruženje u kojem žene dobijaju podršku i razumevanje.

Kulturno geografske teorïje - prema ovoj teoriji različite kockarske aktivnosti predstavljaju različite potkulture koje nisu podjednako atraktivne za oba pola. Prema postulatu ove teorije žene manje preferiraju kockarke aktivnosti kao što su igra kartama i klađenje na trke konja jer su to tradicionalno obeleženi kao muška aktivnosti i lokacije. Dakle, boravak žena na ovakvim mestima potencijalno može biti izvor prezira od strane muškaraca i drugih žena. Međutim, savremeno društvo teži da smanji taj jaz i promeni „mušku kulturu” izgradnjom savremenih objekata, tj.hotela i kazina koji su podjednako privlačni i atraktivni i za žene bez osude. Shodno tome, ova teorija pokušava pružiti objašnjenje zašto žene izbegavaju određena mesta za kockanje (Walker, 1992 prema Delfabbro, 2002; Holdsworth, Hing \& Breen, 2012).

Teorije rodne uloge - teorija rodne uloge se može definisati kao vrednost, norme i očekivanja koje društvo ima $\mathrm{u}$ odnosu na rod. Ova teorija postulira razlike $\mathrm{u}$ ponašanju između muškarca i žena. Posmatrajući tradicionalno žene se nisu kockale često kao muškarci jer to upravo nije bilo u skladu sa njihovom ulogom u gruštvu (Hraba \& Lee, 1996). Društvo „definiše” ulogu žena najpre, ekspresivnu ulogu i „čuvara” ognjišta, dok je muškarcima „propisana“ instrumentalna uloga. U tom smislu kockanje žena bilo bi rasipanje novca, a i pretnja po društvo. Upravo sagledavanje pozadine teorije rodne uloge omogućava razumevanje problema sa kockanjem u kasnijim godinama žena. Njihova tradicionalno rodna uloga bledi, potreba za brigom se smanjuje, deca odlaze od kuće „sindrom praznog gnezda” je sve više zastupljen, neretko dolazi i smrt supružnika, što zasigurno trasira usamljenost. S druge strane, kada je reč o muškarcima, muškost se neretko dokazuje i pokazuje aktivnostima koje zahtevaju veštine i neustrašivost u određenim situacijama (Sibley \& Harre, 2008), kockanje, posebno kockanje sa velikim ulozima pruža im priliku za dokazivanjem koliko mogu biti neustrašivi i vešti. $\mathrm{S}$ obzirom na ovu društvenu normu nije iznenađenje što muškarci u svoj kockarski repertoar uključuju veštine poput blask jack i pokera (LaPlante et al., 2006).

\section{FENOMENOLOŠKE KARAKTERISTIKE KOCKANJA ŽENA}

Literatura ukazuje na postojanje određene rodne demografske vulnerabilnosti za započinjanje sa kockarskim aktivnostima. Kada je reč o životnom ciklusu, podaci sugerišu na ubrzani rast kockanja među mladima, pogotovo $u$ prelasku iz adolescencije u mladu odraslu dob. Studije ponašanja adolescentnog kockanja pokazuju da su devojke manje uključene od dečaka (Dowling et al., 2017). Problem kockanja kod devojaka u odnosu na mladice se kreće od 1:3 do 1:5. Pored ove starosne grupacije vulnerabilna je i starija populacija upravo zbog specifičnosti koji karakteriše ovu dob: penzija, odlazak dece iz roditeljskog doma, „sindrom praznog gnezda”, gde povećava frekventnost kockanja upravo da bi se popunilo vreme gde 
kockanje predstavlja način suočavanja sa viškom vremena, socijalnom izolacijom, usamljenošću, postojanjem fizičkih zdravstvenih problema. Ne treba zanemariti ni faktor rizika u ovoj starosnoj dobi žena koji se može sagledati kroz mehanizam odnosa bračnog stanja i problema. Naime, gubitak partnera rezultira tugom i osećajem gubitka. Gubitak kod žena dovodi do slabljenja otpornosti i većoj podložnosti usamljenosti i kockanju (Berry, Fraehlich \& Toderian, 2002). Postoje i podaci koji se bave ovim temama i ukazuju da odnos pola i gubitka partnera i uključivanje u kockarske aktivnosti karakterističniji za muškarce u odnosu na žene.

Sagledavanjem demografskih odlika žene u kasnijem životnom dobu započinju kockarske aktivnosti. U prilog tome govore rezultati istraživanja (Ladoceur et al., 1994 prema Martins et al., 2002) sprovedenog na 1471 uzorku prosečne starosti oko 18 godina. Autori otkrivaju da je 5,7\% muškaraca u odnosu na $0,6 \%$ žena imalo problem sa kockanjem, što govori u prilog da je odnos muškaraca i žena bio 9,5:1. Drugo istraživanje sprovedeno na uzorku od 1771 prosečne starosti ispitanika oko 22,3 godine ukazuje da se problematično kockanje intenzivira kod žena u odnosu na muškarce i iznosi 4:1. Ovi rezultati potvrđuju tezu da se kasnije javlja problem sa kockanjem kod žena (Lesiuer et al., 1991 prema Martins et al., 2002). Neki autori su mišljenja da nema značajnih razlika po pitanju sociodemografskih karatkeristika između žena i muškaraca. Profil „tipičnog kockara“ bi bio da su njih $76 \%$ starosti između 30 i 49 godina, $67 \%$ oženjeno, $75 \%$ imaju decu, srednjoškolskog obrazovanja $74 \%$, njih $90 \%$ igra poker, $10 \%$ istovremeno je zavisno i od alkohola, $23 \%$ od drugih PAS i 23\% pokušalo samoubistvo (Strachan \& Custer, 1993prema Martins et al., 2002). Sto se tiče žena, razliku pronalaze Tavares i saradnici (2001) jedino po pitanju bračnog statusa $59 \%$ je slobodno i $54 \%$ igra bingo. Međutim, tehnološki razvoj menja i vrstu i dostupnost kockarskih aktivnosti koje utiču na varijabilnost demografskog profila žena. Naime, neki autori pronalaze razlog u osećanju sigurnosti koje pruža internet kockanje i samim tim biva razlog ranijem iskustvu žena u odnosu na muškarce. Međutim, kada se sagledava u globalu ipak mlađe žene imaju manju stopu problema sa kockanjem u odnosu na muškarce (Dowling et al., 2014).

Autori sugerišu da je kao i kod zavisnosti od alkohola i drugih psihoaktivnih supstanci, progresija zavisnosti kockanja kod žena brža u odnosu na muškarce. Ubrzani razvoj zavisnosti kod žena je prepoznat kao „teleskopski efekat”. Kod žena zavisnika od kockanja teleskopski efekat se javlja u dva perioda: prvo u intervalu između intenziviranja kockanja i prvih problema povezanih sa kockanjem i između ovih prvih problema i vremena kada su razvile zavisnost (Grant, Odlaug \& Mooney, 2012 ; Ladd \& Petry, 2002; Grant \& Kim, 2002; Tavares et al., 2001). U prilog tome govore rezultati istraživanja Granta i saradnika sprovedenog 2012. godine na 73 odrasla ispitanika od kojih su 34 činile žene. Prosečna starost žena na početku kockarskih aktivnosti je bila 31,3 godina u odnosu na 22,4 godine koliko je iznosila prosečna starost muškaraca. Žene su imale kraći period od započinjanja kockanja do ispunjavanja kriterijuma za zavisnost od kockanja koji je iznosio oko 8,3 godine, a kod muškaraca je to bilo 11,9 godina (Grant, Odlaug \& Mooney, 2012).

Rodne razlike se protežu i na povezanost kockanja sa višestrukim poremećajima mentalnog zdravlja, što istovremeno povećava mogućnost da problem sa kockanjem 
u većoj meri utiče na genezu i strukturisanje određenih poremećaja. Osvetljavanje ove veze može ići i u pravcu potrebe ublažavanja neprijatnih osećanja gde žene koriste kockanje, ali se sa povećanjem ozbiljnosti kockanja pogoršavaju i simptomi poremećaja. Na postojanje ovakvog komorbiditeta govore rezultati istraživanja i nalaze statističke značajnosti depresije, distimije, socijalnih fobija, generalizovanog anksioznog poremećaja i kockanja kod žena (Desai \& Potenza, 2008; Ellenbogen, Derevensky \& Gupta, 2007; Nower et al., 2004; Potenza, Maciejewski \& Mazure 2006). Podaci studije iz Brazila 78 žena i 78 muškaraca na programu lečenja utvrdila je da su žene više izveštavale o pokušaju samoubistva u odnosu na muškarce (Martins et al., 2004 prema Gavriel-Fried \& Ajzenstadt, 2011). Žene imaju i tendenciju ka asocijalnom ponašanju i senzitivnosti na kritike. U skladu sa navedenim čini se „opravdanim” odabir kockarskih aktivnosti gde je interakcija sa drugim ljudima svedena na minimum. Da je kockanje žena neretko udruženo sa drugim poremećajima svedoče podaci, na primer: sa anoreksijom $55 \%$, bulimijom i to u $11 \%$, kompulsivnom kupovinom u oko $39 \%$ slučajeva češće u odnosu na muškarce (Westphal \& Jonson, 2000 prema Boughton \& Felenchuk, 2007). Muškarci češće prijavljuju konzumaciju alkohola dok se kockaju, te je zloupotreba/zavisnost od alkohola i drugih psihoaktivnih supstanci više zastupljena, a žene zloupotrebu lekova, istoriju lične traume, pozitivna porodična istorija alkoholizma roditelja i drugih mentalnih poremećaja. Njihovi partneri, takođe, najčešće zavisni od alkohola i drugih psihoaktivnih supstanci.

\section{EVOLUTIVNO EKOLOŠKI PRISTUP RIZIKU - RODNE RAZLIKE}

Polazeći od samog termina rizičnosti koji podrazumeva okolnosti izlaganja nekoj opasnosti, dovođenje nečega u pitanje ili stavljanje na kocku nekih vrednosti, dobara i slično (Jugović, 2004), može se sa pravom reći da je kockanje pandam riziku. U ovom slučaju je to kockati se, pa šta sreća donese. Štaviše, predstavlja igranje igre koja uključuje dva elementa slučajnosti i rizika za dobitak ili gubitak značajnog iznosa. Ako je rizik operacionalizovan ulozima, kockari plasiraju rizičnije uloge na više opklada jer takve opklade generišu veći potencijal varijacija u gubicima i dobicima. Kockar ne anticipira posledice nego se rukovodi zadovoljstvom, uglavnom maksimizira očekivanu korist.

S obzirom na to da kockanje uključuje rizičan izbor jer su ishodi nesigurni i potencijalno štetni, za rizičan izbor i ponašanje je značajan način na koji pojedinac/igrač percipira kritične parametre rizika kao što su: opseg potencijalnih ishoda, značenje ishoda i faktore koji određuju verovatnoću ishoda (Spurrier \& Blaszczynski, 2013).

Donošenje odluka ili odlučivanje predstavlja kognitivni proces odabira između ponuđenih mogućnosti, koji se sastoji od prepoznavanja i vrednovanja alternativa koje zadovoljavaju skup postavljenih ciljeva (Johnson \& Bruce, 2008). Odluka o kockanju je proces koji uključuje različite nivoe rizika i neizvesnosti. Rizično donošenje odluke predstavlja kompromis između straha (rizika) i nade (očekivanog dobitka). Što je očekivana vrednost veća, to igru čini poželjnijom. Upravo 
preuzimanjem rizika kockar toleriše mogućnost velikih gubitaka kada bi postigao „materijalnu i psihološku korist”. Varijabilnost u percepciji rizika između muškaraca i žena pokazuje da muškarci imaju tendenciju višeg preuzimanje rizika od žena (Clarke, 2004; Eckel \&Grossman,2008; Harris \& Jenkins, 2006; Mishra, Lalumière \& Williams, 2010; Secades-Villa et al., 2016). Muškarci percipiraju više pozitivne ishode kockanja u odnosu na žene. Takođe, više su usmereni na ugođaj prilikom kockanja i usredsređeni su na veličinu nagrada i traženje opcija sa najvećim mogućim dobicima Suprotno tome, žene su usmerene manjim nagradama. S toga, muškarci u odnosu na žene su skloniji da tolerišu različite rastuće nivoe rizika, kako bi postigli nagradu, a žene pokazuju veću osetljivost na učestalost nagrada (Wong et al., 2013). Pored svega navedenog, važno je napomenuti i doprinos interakcije emocija i donošenja odluke. Tako ciklus uzbuđenja ustupa mesto fantazijama o ishodu, generisan u želji za još jednim pokušajem preokreta. Subjektivno uzbuđenje u ovom slučaju biva pojačano uslužnim osobljem, svetlima, zvukovima i bojama dizajniranim da pojačaju čulne percepcije, uzbuđenje i uživanje, a istovremeno i želju za nastavkom kockanja.

Pored sagledavanja rizičnog ponašanja iz individualne perspektive, literatura ukazuje da ne postoji univerzalna individualna predispozicija za određeno rizično ponašanje među kojima je i kockanje, ali individualne razlike u predispoziciji za upuštanje u rizična ponašanja mogu biti rezultat jedinstvenih gena i izloženosti ekološkim faktorima (Stoltenberg, Batien \& Birgenheir, 2008). Kulturno specifični uticaji deluju putem normi koje utiču na kockanje kao društveno prihvatljivo ponašanje, dok ekološke faktore najpre čine porodični činioci, dostupnost i pristupačnost kao marketing koji oglašavanjem promoviše kockarske aktivnosti. Primeri izloženosti ekološkim faktorima počevši najpre od porodice odnose se na, porodične odnose, zatim stavove i ponašanja roditelja koja doprinose razvoju rizičnog ponašanja (Darbyshire, Oster, \& Carrig, 2001).

Kako se u porodici kroz emocionalnu razmenu stvara klima u kojoj se formira ličnost, preko mehanizama identifikacije izgrađuje identitet i počinje socijabilnost (Milojković, Srna i Mićović, 1997). Tokom procesa primarne socijalizacije dete usvaja norme, vrednosti i obrasce ponašanja koje se smatraju karakterističnim za njegov pol i na taj način kao krajnji rezultat nastaje kulturološki produkovana kategorija roda. Identifikacija sa roditeljima trasira obeležja sa kojima će se dete naknadno identifikovati (Bazić i Pešić, 2012). U porodici su muškarci podsticani da učestvuju u takmičarskim aktivnostima, najpre, u sportovima gde se na preuzimanje rizika gleda kao deo muškog rodnog identiteta, dok se devojčice podstiču da ostanu oprezne i izbegavanje rizika postaje deo identiteta ženskog roda. Štaviše, društvena očekivanja od muškaraca su začeta još u porodici, gde se muškarci koji rizikuju vrednuju kao sposobni, uspešni, socijalno poželjniji i privlačniji čak i za žene.

Porodica upoznavanjem kroz sopstveno učešće u kockarskim aktivnostima pokazuje sopstvene stavove o kockanju koji normalizuju kockanje kroz ponašanje kao što je: obezbeđivanje novca za kockanje, kupovina tiketa, aktivno podsticanje. Porodice time postavljaju norme u okviru kojih se kockanje posmatra u pozitivnom svetlu. Međugeneracijski prenos kockanja može biti i kroz prizmu finansijske i druge prednosti kockanja u smislu bezopasne porodične igre ili načina provođenja 
slobodnog vremena (Campbell et al., 2011). Tako porodica postaje prihvatljivo okruženje za kockanje i postiže efekat generacijskog multiplikatora kroz reprodukciju normi, ponašanja i stavova o kockanju sa roditelja na decu (Abbott, Romild \& Volberg, 2018). Ovakvi stavovi porodice postaju doprinoseći činioci ranog započinjanja kockanja što otvora put ka generisanju i strukturisanju, najpre, problematičnom, a zatim i zavisnosti od kockanja (Dowling et al., 2017). Drugi autori ističu da deca problematičnih kockara imaju četiri puta veći rizik uključivanja u kockarske aktivnosti u odnosu na svoje vršnjake (Abbott et al., 1995 prema Darbyshire, Oster \& Carrig, 2001). Ako se ovome doda i rodni način usvajanja kockarskih aktivnosti, postaje uobičajeno prvo iskustvo devojaka sa kockanjem kroz kockanje njihovih majki, dok muškarci to čine preko očeva.

Dostupnost i pristupačnost mesta za kockanje se izdvaja kao značajan faktor kockanja žena. Tehnološki napredak savremenog doba koji oblikuje individualistički životni stil, koji sve to "olakšava" u smislu pristupačnosti i mogućnosti kockanja preko mobilnih telefona, tableta, računara, a sve se može odvijati u dnevnoj sobi, ćaskanje uz igranje on-line pokera (McCormack, Shorter \& Griffiths, 2014). Mogućnost kockanja od kuće ne nudi samo dostupnost, lakoću i sigurnost ženama da se oprobaju u različitim igračkim aktivnostima u tajnosti, tj.bez opasnosti od podsmeha drugih. U skladu sa tim, može se reći da je danas moguće kockati u bilo koje doba dana, u različitim zemljama sveta, uz mogućnost on-line plaćanja, što čini da mogućnost za kockanje postaje neograničena.

Da je faktor sigurnosti uvek bio važan za žene, podupire studija bingo igrača. U Engleskoj je još 8o-tih godina prošlog veka identifikovano nekoliko faktora koji su uticali na kockanje žena: fleksibilno radno vreme, lokalna raspoloživost, niska cena i sigurnost mesta (Dikei, 1996 prema Volberg, 2003). Iz sadašnje perspektive čini se da su razlozi žena isti, samo su dobili savremeniju varijantu ispunjavanja zahteva. Iako se u prvi mah čini da on-line kockanje ima mnogo „pozitivnih“ strana, ne treba zanemariti njegov adiktivni potencijal, posebno postaje opasno za pojedine grupe kao što su žene sa malom decom, starije žene, invalide koji dosta vremena provode u kući i obavljaju poslove vezane za kuću (Håkansson \& Widinghoff, 2020). Ovakav "olak" način kockanja otežava apstinenciju i usložnjava problem.

Naposletku, ništa manje važnu treba dodati i kockarsku industriju koja nakon muškaraca svoju pažnju usmeravaju na drugu ciljnu grupu -žene, smatrajući ih veliko a nedovoljno iskorišćeno "tržište"(Corney \& Davis, 2010). Veb-lokacije postaju orijentisane ka ženama, sa dizajnom i slikama kao i sadržajem koji imaju za cilj privući što veći broj žena da participiraju u kockarskim igrama (Håkansson \& Widinghoff, 2019).Oslanjaju se na već poznatu vulnerabilnost žena i potrebu za socijalnom interakcijom. Kao sredstvo koriste glamur i žene poznate ličnosti da promovišu „svoje proizvode”, i da je kockanje finansijski i emocionalno korisna aktivnost. 
Zbornik IKSI, 1/2O21 - S. Milošević

„Karakteristike kockanja kod žena”, (str. 85-102)

\section{RODNE RAZLIKE U MOTIVACIJI I SKLONOSTI KOCKARSKIH AKTIVNOSTI}

Imajući u vidu da je za neke pojedince kockanje sporadična aktivnost za zabavu, za druge „strast“ dok za treće može biti „razarajuća“ aktivnost koja izaziva brojne posledice (Sundqvist, Jonsson \& Weinberg, 2016). S obzirom, da pojedinci različito reaguju na iste situacije, što sugeriše da imaju različite skolnosti u ponašanju (Deci \& Ryan, 1985 prema Lamont, Hing \& Gainsbury, 2011), odgovor za kockarske aktivnosti koje se kreću ovom linearnom putanjom može se delimično pronaći i u motivaciji. To potvrđuje i definicija motivacije kao unutrašnja i/ili spoljna sila koja pokreće i usmerava, pojačava i vodi na upornost u ponašanju (Lee et al., 2007). Prema teoriji očekivanja, motivacija može biti rezultat privlačnosti cilja, to jeste, pretpostavlja se da izbor ponašanja zavisi od očekivanja privlačnog ishoda koji za pojedinca ima važnost ili potencijal nagrade i verovanju da će ga radnja dovesti do cilja, a nagrada će zadovoljiti važne potrebe koje su dovoljno jake da se uloženi trud čini smislenim (Ibánez et al., 2003; Lamont \&Hing,2001;Lamont, Hing \& Gainsbury, 2011). U skladu sa tim, motivacija odražava različita očekivanja kockara kao što su pozitivni aspekti kockanja s jedne strane, dok s druge strane ima potencijal za ublažavanje negativnih emocija.

Žene su kockanje označile kao želju da pobegnu usamljenosti, depresije, napetosti i stresa koju stvaraju socijalni zahtevi kao što su zahtevi domaćinstva i radnog mesta koji se postavljaju pred žene, zatim dosade i socijalne izolacije. U skladu s tim birale su igre koje bi maksimizirale njihovo vreme (Gavriel-Fried \& Ajzenstadt, 2011; Hing \& Breen, 2001; Li, 2007; Toneatto \& Wang, 2009). U početku se kockanje učini dobrim „rešenjem“, ali ubrzo dobija drugo lice kada kockanje postaje izvor stresa i narušavanje interpesonalnih odnosa, to jeste, nastaje paradoksalna situacija ono što je bilo „rešenje“ postaje izvor psihološke patnje naročito za kompulsivne kockare.

Drugi motiv je iz socijalnih razloga, gde se žene kockaju da bi bile u društvu drugih ljudi. Smatra se da je socijalna izolacija ključni motivator za započinjanje kockanja, ali i jedan od doprinosećih činilaca razvoja problema sa kockanjem. Okruženje poput klubova predstavljaju mesta koja olakšavaju socijalnu interakciju. Ljubazno osoblje i menadžeri doprinose da zaborave na usamljenost i izolaciju (Sundqvist, Jonsson \& Wennberg, 2016). Međutim, ne treba zanemariti da usamljenost može imati i drugo zaleđe. Naime „usamljenost“ može rasti paralelno sa gubitkom kontrole nad kockanjem kada nemaju kome da se obrate, jer niko ne razume njihove „nevolje“. Tako socijalna izolacija poprima dvostruku ulogu bilo kao pokretač kockanja ili kao posledica kumulativnog problema sa kockanjem (Holdsworth, Hing \& Breen, 2012). Potencijani motiv može biti i percepcija dominacije nad muškarcima u nekim sredinama čini kockanje privlačnom aktivnošću za žene.

Nasuprot tome, muškarci kockanjem uglavnom zadovoljavaju potrebu za uzbuđenjem, uživaju u „naletu adrenalina“ povezanim sa igrom, jačanjem ega, potvrdom muškosti, senzacijama, verovanje da mogu uticati na ishod igre kao i pogrešnim naporima da zarade novac (Wenzel \& Dahl, 2009). Kada se u obzir uzme 


\author{
Zbornik IKSI, 1/2021 - S. Milošević \\ „Karakteristike kockanja kod žena”, (str. 85-102)
}

kockanje adolescenata, muški adolescenti u odnosu na devojke više su motivisani da kockaju kako bi pobegli od problema, zaradili novac, osećali bolje i zabavili (Jackson et al., 2008).

Rodno istraživanje usmereno na izbor kockarskih aktivnosti ukazuje da je preferencija kockarskih aktivnosti žena neretko i varijabilna. Najpre, njihova prva iskustva sa kockanjem još u ranoj mladosti i uglavnom su to loto, greb-greb (Baggio et al., 2018; Elton-Marshall et al., 2016). Sa odrastanjem se nastavljaju aktivnosti zasnovane na sreći i izbegavaju igre veština pravdajući se neretko nedostatkom neophodnog „znanja” za određene igre, odlučuju za manji novčani rizik i praktikuju igre poput automata i binga, sa jedne strane, ali s druge strane, ima podataka da postoje primeri žena koje uz rodno karakteristične nestrateške igre praktikuju i igre zasnovane na veštinama i sve veći udeo žena koje učestvuju u klađenju na konjskim trkama (Holdsworth, Hing \& Breen, 2012).

Za razliku od njih, muškarci uglavnom preferiraju akciono orijentisane strateške oblike kockanja koje zahtevaju veći stepen preuzimanja rizika i veština kao što su trke konja, sportsko klađenje, black jack i poker.

Na slične podatke ukazuje $\mathrm{i}$ istraživanje sprovedeno u Srbiji na 3111 ispitanika ukazuje da je kockanje pet puta više rasprostranjeno među muškarcima nego devojkama, odnosno $54 \%$ naspram $11 \%$. Najpre, $28 \%$ je posećivalo sportske kladionice, 8\% igra poker i 3\% kazino. Oko 50\% muškaraca između 17 i 35 godina učestvuje u sportskom klađenju naspram 6\% devojaka (Jugović, 2004).

Postoje i podaci koji ukazuju da akcione igre kao što su greb-greb, loto, omiljene su igre mladih bez obzira na rod. Istraživanje sprovedeno u Velikoj Britaniji ukazuje da $64 \%$ mladih igra loto povremeno, $16 \%$ veći deo vremena tokom godine, $14 \%$ jednom tokom svake nedelje (Wood \& Griffits, 2002).

\title{
STIGMATIZACIJA KOCKANJA- KOMPARATIVNA ANALIZA
}

Poput drugih poremećaja, i zavisnost od kockanja je praćena stigmom i diskriminacijom. Stigma može biti doživljena, kada predstavlja aktuelno iskustvo diskriminacije ili internalizovana, kada ukazuje na strah od diskriminacije ili osećanje sramote, stida, skrivanja, povlačenja usled toga što se negativni stereotip prihvata (Corrigan, 1998 prema Milačić-Vidojević i Dragojević, 2011). Traženje pomoći pojedinaca koji imaju problem sa kockanjem je odloženo zbog stigme i diskriminacije. Podaci ukazuju da samo $25 \%$ ljudi će potražiti pomoć zbog problema sa kockanjem. Kao razlog jeste namera da se izbegne sramota i strah od stigme koja predstavlja važan prediktivni faktor odloženog pružanja pomoći. Literatura ukazuje na postojanje rodne percepcije stigma i traženja pomoći. Muškarci su izveštavali da finansijski gubici stvaraju stigmu i predstavljaju prepreku u traženju pomoći, dok žene da osećaj sreće i zabavna priroda kockanja predstavlja prepreku. Međutim, presudno je priznavanje pred drugima da je usamljena i priznanje da se kockala da bi se povezala sa drugima. Tako za žene biva sramno priznanje da su ih „zavela” mesta gde se osećaju važnim, poricanje zavisnosti, sramota zbog neiskrenosti i verovanje u sreću odlažu traženje pomoći (Suurvali et al., 2008 prema Baxter et al., 
2016). Žene odlažu pomoć uglavnom jer negiraju problem, strahuju da ce izgubiti važnu društvenu vezu koju su stekle kockanjem, ne treba zanemariti i da je društvena percepcija kockanja žena negativnija u odnosu na muškarce (Hing et al., 2015; Potenza et al., 2001). Istraživanje Horhea i Hodžinsa (Horch \& Hodgins, 2008) pokazuje da se ljudi žele distancirati od pojedinaca nakon saznanja da imaju problem sa kockanjem i to posebno kada su muškarci u pitanju.

\section{ZAKLJUČNA RAZMATRANJA}

Sublimacijom i analizom prikazanih rezultata istraživanja može se zaključiti da žene koje se bore sa ličnim, porodičnim problemima, imaju iskustvo gubitka voljenih osoba su sklonije kockanju. U poređenju sa muškarcima, žene počinju kockati u kasnijoj životnoj dobi, ali i imaju bržu progresiju u zavisnost.

Imajući u vidu sve navedeno, nedvosmisleno se nameće potreba sistematičnijeg istraživanja kako u drugim zemljama tako i u našoj. Posebnu pažnju bi trebalo usmeriti na razumevanje ličnih, porodičnih, socioekonomskih i kulturnih okolnosti koje su povezane sa kockarskim aktivnostima.

Rodni pristup je od suštinske važnosti kako bi se razvile efikasne strategije poboljšanja zdravlja i zadovoljile potrebe ove grupe stanovništva.Ništa manje značajno, društvo bi trebalo da usmeri svoje resurse na promociju javnog zdravlja kroz programe prevencije kako za celu populaciju, tako i za vulnerabilne grupe o opasnosti prelaska iz rekreativnog kockanja u zavisnost od kockanja, politiku smanjenja štete i osmišljavanje rodno specifičnih programa tretmana imajući u vidu da žene imaju kulturne i rodne karakteristike kao što su:deficit samopouzdanja i veština rešavanja problema. Sve ovo nam potvrđuje da se ovim specifičnostima može baviti samo u rodno osetljivom ili rodno specifičnom tretmanu.

Ono što je sasvim jasno jeste da kockanje koliko god popularno bilo u savremenom društvu, još uvek je tema koju karakteriše tajnost i stigma i upućuje na preporuku da bi se izbeglo stereotipno mišljenje i osuđivanje žena, programi lečenja treba da budu usmereni ka deinstitucionalizaciji kroz otvaranje grupa za podršku i iznalaženje rodnih alternativnih aktivnosti.

\section{LITERATURA:}

(1) Abbott, M., Romild, U., \& Volberg, R. (2018) The prevalence, incidence, and gender and age specific incidence of problem gambling: Results of the Swedish longitudinal gambling study (Swelogs). Addiction, 113(4), 699-707.

https://doi.org/ 10.1111/add.14083

(2) Ashley. L. L., \& Boehlke, K. K. (2012) Pathological Gambling: A General Overview. Journal of Psychoactive Drugs, 44(1), 27-37. https://doi.org/10.1080/02791072.2012.662078

(3) Baggio, S., Gainsbury, S. M., Starcevic, V., Richard, J.-B., Beck, F., \& Billieux, J. (2018) Gender differences in gambling preferences and problem gambling: a 


\author{
Zbornik IKSI, 1/2O21 - S. Milošević \\ „Karakteristike kockanja kod žena”, (str. 85-102)
}

network-level analysis. International Gambling Studies, 18(3), 515-525.

https://doi.org/10.108o/14459795.2018.1495750

(4) Baxter, A., Salmon, C., Dufresne, K., Carasco-Lee, A., \& Matheson, F. I. (2016)

Gender differences in felt stigma and barriers to help-seeking for problem gambling.

Addictive Behaviors Reports, 3, 1-8. https://doi.org/10.1016/j.abrep.2015.10.001

(5) Bazić, J. \& Pešić, M. (2012) Sociologija. Leposavić: Učiteljski fakultet.

(6) Binde, P. (2009) Exploring the Impact of Gambling Advertising: An Interview Study of

Problem Gamblers, 7(4), 541-554. https://doi.org/10.1007/s11469-008-9186-9

(7) Bjelajac, Ž. (2017) Patološko kockanje i kriminal. Kultura Polisa, 14(3-4), 185-201.

(8) Boughton, R., \& Falenchuk, O. (2007) Vulnerability and comorbidity factors of female problem gambling. Journal of Gambling Studies, 23(3), 323-334.

https://doi.org/10.1007/s10899-007-9056-6

(9) Božović, R. (2013) Igra ili ništa .Beograd. Čigoja

(10) Campbell,C.,Derevensky,J.,Meerkamper,E.,\&Cutajar,J.(2011)Parents Perceptions of Adolescent Gambling:A Canadian National Study. Journal of Gambling Issues, 25(25), 36-53. hhtps://doi.org/10.4309/jgi.2011.25.4

(11) Clarke, D. (2004) Impulsiveness, locus of control, motivation and problem gambling. Journal of Gambling Studies. 20(4), 319-345.

https://doi.org/10.1007/s10899-004-4578-7

(12) Corney, R. \& Davis, J. (2010) The attractions and risks of Internet gambling for women: A qualita study .Journal of Gambling Issues, 24, 121-139.

https://doi.org/10.4309/jgi.2010.24.8

(13) Darbyshire, P., Oster, C., \& Carrig, H. (2001) Children of parent(s) who have a gambling problem: a review of the literature and commentary on research approaches. Health \& Social Care in the Community, 9, 185-193.

https://doi.org/10.1046/j.0966-0410.2001.00302.x

(14) Delfabbro, P. (2002) Gender differences in Australian Gambling: A critical summary of sociological and psychological research. Australian Journal of Social Issues, 35(2), 145-158. https://doi.org/10.1002/j.1839-4655.2000.tbo1091.x

(15) Desai, R.A., \& Potenza, M.N. (2008) Gender differences in the associations between past-year gambling problems and psychiatric disorders. Social Psychiatry and Psychiatric Epidemiology, 43(3), 173-183. https://doi.org/10.1007/s00127-0070283-Z

(16) Dowling, N. A., Jackson, A. C., Suomi, A., Lavis, T., Koziol-McLain, J., \&Thomas, S. A. (2014) Problem gambling and family violence: Prevalence and patterns in helpseeking populations. Addictive Behaviors, 39, 1713-1717. https://doi.org/10.1016/j.addbeh.2014.07.006

(17) Dowling, N.A., Merkouris, S.S., Greenwood, C.J., Oldenhof, E., Toumbourou, J.W., \& Youssef, G.J. (2017) Early risk and protective factors for problem gambling: A systematic review and meta-analysis of longitudinal studies. Clinical Psychology Review 51(2), 109-124. https://doi.org/10.1016/j.cpr.2016.10.008

(18) Eckel C., \&Grossman, P. (2008) Forecasting risk attitudes: An experimental study using actual and forecast gamble choice. Journal of Economic Behavior \& Organization, 68(1), 1-17. https://doi.org/10.1016/j.jebo.2008.04.006

(19) Ellenbogen, S., Derevensky, J., \& Gupta, R. (2007) Gender differences among adolescents with gambling-related problems. Journal of Gambling Studies, 23(2), 133-143 https://doi.org/10.1007/s10899-006-9048-y

(20) Elton-Marshall, T., Leatherdale, S. T., \& Turner, N. E. (2016). An examination of internet and land-based gambling among adolescents in three Canadian provinces: results from the youth gambling survey (YGS). BMC Public Health, 16(1), 277-278. https://doi.org/ 10.1186/s12889-016-2933-0 


\author{
Zbormik IKSI, 1/2O21 - S. Milošević \\ „Karakteristike kockanja kod žena”, (str. 85-102)
}

(21) Farré, J. M., Fernández-Aranda, F., Granero, R., Aragay, N., Mallorquí-Bague, N., Ferrer, V., Jiménez-Murcia, S. (2015) Sex addiction and gambling disorder: similarities and differences. Comprehensive Psychiatry, 56, 59-68. https://doi.org/10.1016/j.comppsych.2014.10.002

(22) Gavriel-Fried, B., \& Ajzenstadt, M. (2011) Pathological Women Gamblers: GenderRelated Aspects of Control. Sex Roles: A Journal of Research, 66(1-2), 128-142. https://doi.org/10.1007/s11199-011-0071-9

(23) Grant, J. E., Desai, R. A., \& Potenza, M. N. (2009) Relationship of nicotine dependence, subsyndromal and pathological gambling, and other psychiatric disorders: Data from the National Epidemiologic Survey on Alcohol and Related Conditions. The Journal of Clinical Psychiatry, 7o(3), 334-343. https://doi.org/10.4088/JCP.o8mo4211

(24) Grant, J. E., Odlaug, B. L., \& Mooney, M. E. (2012) Telescoping Phenomenon in Pathological Gambling: Association with Gender and Comorbidities. The Journal of Nervous and Mental Disease, 200(11), 996-999. https://doi.org/10.1097/NMD.obo13e3182718a4d

(25) Grant, J.E., \& Kim, S.W. (2002) Gender differences in pathological gamblers seeking medication treatment. Comprehensive Psychiatry, 43(1), 56-62. https://doi.org/10.1053/comp.2002.29857

(26) Gupta, R., \& Derevensky, J.L. (2000) Adolescents with gambling problems: From research to treatment. Journal of Gambling Studies, 16(2), 315-342. https://doi.org/10.1023/A:1009493200768

(27) Håkansson, A., \& Widinghoff, C. (2019) Television gambling advertisements: Extent and content of gambling advertisements with a focus on potential high-risk commercial messages. Addictive Behaviors Reports, 9, 100182. https://doi.org/10.1016/j.abrep.2019.100182

(28) Håkansson, A., \& Widinghoff, C. (2020) Gender Differences in Problem Gamblers in an Online Gambling Setting.Psychology Research and Behavior Management, 13, 681-691. https://doi.org/10.2147/PRBM.S248540

(29) Harris, C.R., \& Jenkins, M. (2006) Gender Differences in Risk Assessment: Why do Women TakeFewer Risks than Men? Judgment and Decision Making, 1(1), 48-63.

(30) Hing, N., \& Breen, H. (2001) An empirical study of sex differences in gaming machine play amongst club members. International Gambling Studies,1(1),67-86. https://doi.org/10.1080/14459800108732288

(31) Hing, N., Russell, A. M. T., Gainsbury, S. M., \& Nuske, E. (2015) The Public Stigma of Problem Gambling: Its Nature and Relative Intensity Compared to Other Health Conditions. Journal of Gambling Studies, 32(3), 847-864. https://doi.org/10.1007/s10899-015-9580-8

(32) Holdsworth, L., Hing, N., \& Breen, H. (2012) Exploring women's problem gambling: A review of the literature. International Gambling Studies, 12(2), 199-213. https://doi.org/10.1080/14459795.2012.656317

(33) Horch, J.D., D. C., \& Hodgins, D. C. (2008) Public stigma of disordered gambling: Social distance, dangerousness, and familiarity. Journal of Social and Clinical Psychology, 27(5), 505-528. https://doi.org/10.1521/jscp.2008.27.5.505

(34) Hraba, J., \& Lee, G. (1996) Gender, gambling and problem gambling. Journal of Gambling Studies, 12(1), 83-101. https://doi.org/10.1007/BF01533191

(35) Ibánez, A., Blanco, C., Moreryra, P., \& Saíz-Ruiz, J. (2003) Gender differences in pathological gambling. Journal Clinical Psychiatry, 64(3), 295-301. https://doi.org/10.4088/JCP.v64no311

(36) Jackson,A.C.,Dowling,N.,Thomas,S.A.,Bond,A.,\&Patton,G.(2008) Adolescent Gambling Behaviour and Attitudes: A Prevalence Study and Correlates in an 


\author{
Zbormik IKSI, 1/2O21 - S. Milošević \\ „Karakteristike kockanja kod žena”, (str. 85-102)
}

Australian Population. Intenational Journal Mental Health Addiction, 6(3), 325352. https://doi.org/10.1007/s11469-0o8-9149-1

(37) Jasaeri, S., \& Bin Habil, M. (2012) Reviewing Two Types of Addiction - Pathological Gambling and Substance Use. Indian Journal of Psychological Medicine, 34(1), 511. https://doi.org/10.4103/0253-7176.96147

(38) Johnson, J., \& Bruce, A. (2008) Decisions: Risk and Reward. New York: Routledge.

(39) Jugović, A. (2004) Rizična ponašanja omladine. U: M. Nikolić i S. Mihailović (Ur.) Mladi zagubljeni u tranziciji, str. 177-204. Beograd, Centar za proučavanje alternativa.

(40) Khanbhai, Y., Smith, D., \& Battersby, M. (2017) Gender by Preferred Gambling Activity in Treatment Seeking Problem Gamblers: A Comparison of Subgroup Characteristics and Treatment Outcomes. Journal of Gambling Studies, 33(1), 99113. https://doi.org/10.1007/s10899-016-9614-x

(41) Koić, E., Đorđević, V., Filakovic, P., \& Nađ, S. (2009) Problem and Pathological Gambling. Collegium Antropologicum, 33(3), 961-971.

(42) Koprek, I. (2013) Sreća i igre na sreću. Etički okvir za razumijevanje jednog fenomena današnjice. Nova prisutnost: Časopis za intelektualna i duhovna pitanja, 11(3), 367-377.

(43) Ladd, G. T., \& Petry, N. M. (2002) Gender differences among pathological gamblers seeking treatment.Experimental and Clinical Psychopharmacology, 10(3), 302309. https://doi.org/10.1037/1064-1297.10.3.302

(44) Lamont, M., Hing, N., \& Gainsbury, S. (2011) Gambling on sport sponsorship: A conceptual framework for research and regulatory review.Sport Management Review, 14(3), 246-257. https://doi.org/10.1016/j.smr.2011.04.004

(45) LaPlante, D., Nelson, S., LaBrie, R., \& Shaffer, H. (2006) Men and women playing games: Gender and the gambling preferences of Iowa gambling treatment program participants. Journal of Gambling Studies, 22(1), 65-80. https://doi.org/10.1007/s10899-005-9003-3

(46) Lee, H. P., Chae Kyuman, P., Lee, H. S. \& Kim, Y. (2007) The five-factor gambling motivation model. Psychiatry Research, 15O(1), 21-32. https://doi.org/10.1016/j.psychres.2006.04.005

(47) Li, J. (2007) Women's ways of gambling and gender-specific research. Sociological Inquiry, 77(4), 626-636. https://doi.org/10.1111/j.1475-682X.2007.00211.x

(48) Martins, S.S., Lobo, D., Tavares, H., \& Gentil, V. (2002) Pathological gambling in Women. A review Revista do Hospital das Clínicas, 57(5), 235242.https://doi.org/10.1590/So041-87812002000500008

(49) McCormack, A., Shorter, G. \& Griffiths, M.D. (2014). An empirical study of gender differences in online gambling. Journal of Gambling Studies, 30, 71-88. https://doi.org/ 10.1007/s10899-012-9341-x

(50) Merkouris, S.S., Thomas, A. C., Shandley, K. A., Rodda, S. N., Oldenhof, E., \& Dowling, N.A.(2016)An update on gender differences in the characteristics associated with problem gambling:A systematic review.Current Addiction Reports,3(3),254-267. .https://doi.org/10.1007/s40429-016-0106-y

(51) Milačić-Vidojević,I.,i Dragojević,N.(2011)Stigma i diskriminacija prema ososbama s mentalnom bolešću i članovima njihovih porodica. Specijalna edukacija $i$ rehabilitacija, 10(2), 319-337.

(52) Milojković, M., Srna, J., i Mićović, R. (1997) Porodična terapija. Beograd: Centar za brak i porodicu.

(53) Mishra, S., Lalumière, M. L., \& Williams, R. J. (2010) Gambling as a form of risktaking: Individual differences in personality, risk-accepting attitudes, and 


\author{
Zbornik IKSI, 1/2021 - S. Milošević \\ „Karakteristike kockanja kod žena”, (str. 85-102)
}

behavioral preferences for risk. Personality and Individual Differences, 49(6), 616621. https://doi.org/10.1016/j.paid.2010.05.032

(54) Nower, L., Gupta, R., Blaszczynski, A., \& Derevensky, J.L. (2004) Suicidality and depression among youth gamblers: A preliminary examination of three studies. International Gambling Studies, 4(1), 69-80. https://doi.org/10.1080/1445979042000224412

(55) Nuske, E., Holdsworth, L., \& Breen, H. (2016) Significant life events and social connectedness in Australian women's gambling experiences. Nordic Studies on Alcohol and Drugs, 33(1), 7-13. https://doi.org/10.1515/nsad-2016-0oo

(56) Petry, N. M. (2002) A comparison of young, middle-aged, and older adult treatment-seeking pathological gamblers. Gerontologist, 42(1), 92-99. https://doi.org/10.1093/geront/42.1.92

(57) Petry, N. M., Blanco, C., Stinchfield, R., \& Volberg, R. (2013) An empirical evaluation of proposed changes for gambling diagnosis in the DSM-5. Addiction, 108(3), 575-581. https://doi.org/10.1111/j.1360-0443.2012.04087.x

(58) Potenza, M.N., Maciejewski, P K., \& Mazure, C.M. (2006) A gender-based examination of past-year recreational gamblers. Journal of Gambling Studies, 22(1), 41-64. https:doi.org/10.1007/s10899-005-9002-4

(59) Potenza, M.N., Steinberg, M.A., McLaughlin, S.D., Wu, R., Rounsaville, B.J., \& O'Malley, S.S. (2001) Gender-related differences in the characteristics of problem gamblers using a gambling helpline. American Journal of Psychiatry, 158(9), 1500-1505. https:doi.org/10.1176/appi.ajp.158.9.1500

(6o) Secades-Villa, R., Martínez-Loredo, V., Grande-Gosende, A., \& Fernández-Hermida, J. R. (2016) The Relationship between Impulsivity and Problem Gambling in Adolescence. Frontiers in Psychology, 7(3), 1931-1938.

https:/doi.org/10.3389/fpsyg.2016.01931

(61) Sibley, C. G., \& Harré, N. (2009) The impact of different styles of traffic safety advertisement on young drivers' explicit and implicit self-enhancement biases. Transportation research part F: traffic psychology and behaviour, 12(2), 159-167. https://doi.org/10.1016/j.trf.2008.11.001

(62) Sproston, K., Hing, N., \& Palankay, C. (2012) Prevalence of gambling and problem gambling in New South Wales. Sydney: Ogilvy Illumination.

(63) Spurrier, M., \& Blaszczynski, A. (2013) Risk Perception in Gambling: A Systematic Review. Journal of Gambling Studies, 30(2), 253-276. https://doi.org/10.1007/s10899-013-9371-z

(64) Stoltenberg, S. F., Batien, B. D., \& Birgenheir, D. G. (2008) Does gender moderate associations among impulsivity and health-risk behaviors? Addiction Behaviour,33(2),252-265. https://doi.org/10.1016/j.addbeh.2007.09.004

(65) Subramaniam, M., Chong, S. A., Satghare, P., Browning, C. J., \& Thomas, S. (2017) Gambling and family: A two-way relationship.Journal of Behavioral Addictions,6(4),689-698. https://doi.org/10.1556/2006.6.2017.082

(66) Sundqvist, K., Jonsson, J., \& Wennberg, P. (2016) Gambling Motives in a Representative Swedish Sample of Risk Gamblers, Journal of Gambling Studies, 32(4), 1231-1241. https://doi.org/10.1007/s10899-016-9607-9

(67) Tavares, H., Zilberman, M. L., Beites, F. J., \& Gentil, V. (2001). Brief communications: Gender differences in gambling progression. Journal of gambling studies, 17(2), 151-159. https://doi.org/10.1023/a:1016620513381

(68) Toneatto, T., \& Wang, J.J. (2009) Community treatment for problem gambling: Sex differences in outcome and process. Community Mental Health Journal, 45(6), 468-475. https://doi.org/10.1007/s10597-009-9244-1 
(69) Tse, S., Hong, S.I., Wang, C.W., \& Cunningham-Williams, R.M. (2012) Gambling behavior and problems among older adults: a systematic review of empirical studies. Journals of Gerontology Series B: Psychological Sciences and Social Sciences, 67(5), 639-652. https://doi.org/10.1093/geronb/gbso68

(70) Volberg, R. (2003) Has there been a "feminization" of gambling and problem gambling in the United States? Journal of Gambling Issues, 8, 44-52. http://doi.org/10.4309/jgi.2003.8.7

(71) Wenzel, H. G., \& Dahl, A. A. (2009) Female pathological gamblers-A critical review of the clinical findings. International Journal of Mental Health and Addiction, 7(1), 190-202. https://doi.org/10.1007/s11469-008-9174-o

(72) Wong, G., Zane, N., Saw, A., \& Chan, A. K. K. (2013). Examining gender differences for gambling engagement and gambling problems among emerging adults. Journal of gambling studies, 29(2), 171-189. https://doi.org/10.1007/s10899-012-9305-1

(73) Wood, R., \& Griffiths, M. (2002) Adolescent perception of the national Lottery and Scratchcards: a qualitative study asusng group interviews.Journal Adolescence, 25(6), 655-668. https://doi.org/10.1006/jado.2002.0515

\section{Internet izvor:}

(74) Gambling Comision (2017). Gambling participation in: behaviour, awareness and attitudes, Annual report 2017.

https://www.gamblingcommission.gov.uk/PDF/survey-data/Gamblingparticipation-in-2017-behaviour-awareness-and-attitudes.pdf stranici pristupljeno 27.10.2020

(75) Berry, R.E., Fraehlich, C., \& Toderian, S. (2002).Womens Experiences of gambling and problem gambling https://www.greo.ca/Modules/EvidenceCentre/files/Berry\%2oet\%20al(2002)Wo mens_experiences_of_gambling_and_PG.pdf stranici pristupljeno 20.1.2021. 


\section{CHARACTERISTICS OF WOMEN'S GAMBLING}

The aim of this paper is to consider the results of research on the characteristics of women 's gambling and to explain the gender differences in gambling. Gambling today is a ubiquitous multidimensional social phenomenon involving an increasing number of populations. Precisely because of the impact on the overall rate of braking problems in the general population and, more importantly, on certain risk groups in the population, first of all young people, adults, both men and women, cause great concern. Despite an estimate that one-third of gamblers are women, most of the gambling literature focuses mainly on men's gambling behavior and attitudes. Comparative analyzes between men and women show differences in the characteristics of women, such as: demographic sensitivity, progression of addiction, motivation and choice of gambling activities. Women often postpone seeking professional help due to shame and fear of stigmatization. A better understanding of gender differences in women is necessary to define effective prevention strategies and implement gender-sensitive treatment programs.

KEY WORDS: gambling addiction / gambling women / motivation / types of gambling games 